\title{
Isolasi DNA pada Sampel Darah Tepi dan Swab Buccal pada Bayi Penderita ROP: Perbandingan Hasil Uji Konsentrasi dan Indeks Kemurnian
}

\author{
Jo Edy Siswanto, ${ }^{*}$ Tiara Berlian, ${ }^{* *}$ Evira Putricahya, ${ }^{* * *}$ Lidya V. Panggalo, ${ }^{* * *}$ Luluk Yuniani**** \\ * RSAB Harapan Kita, Jakarta **Departemen Biologi FMIPA FK UNPAD, Bandung \\ *** Departemen Biologi FMIPA FKUI Jakarta ${ }^{* * * *}$ Departemen Biologi FKUI
}

\begin{abstract}
Latar belakang. Retinopati prematuritas (ROP) adalah gangguan perkembangan dari pembuluh darah retina yang mengenai bayi prematur. Faktor genetik diduga berperan terhadap kejadian ROP. Konsentrasi dan kemurnian DNA hasil isolasi diperlukan untuk analisis pemeriksan genetik pada kasus ROP.

Tujuan. Mengetahui konsentrasi dan indeks kemurnian DNA menggunakan sampel whole blood, buffy coat dan swab buccal pada kelompok bayi-bayi prematur yang masuk dalam kriteria penapisan ROP.

Metode. Enam puluh dari total 182 subyek yang terdiagnosis ROP terpilih dengan systematic random sampling. Konsentrasi dihitung melalui penyerapan spektrofotometrik sinar ultraviolet. Kemurnian ditentukan dengan menghitung rasio antara OD260 dan nilai OD280. Analisis statistik dilakukan dengan uji Kruskal Wallis dan Mann Whitney.

Hasil. Uji konsentrasi DNA menggunakan sampel buffy coat lebih tinggi dibandingkan whole blood dan swab buccal. Sampel whole blood mempunyai indeks kemurnian yang paling baik.

Kesimpulan. Konsentrasi DNA sampel buffy coat dan whole blood cukup tinggi dengan indeks kemurnian yang baik untuk analisis genetika. Sari Pediatri 2016;18(4):270-7
\end{abstract}

Kata kunci: isolasi DNA, konsentrasi dan indeks kemurnian, ROP

\section{DNA Isolation in Blood and Buccal Swab Samples in Retinopathy of Prematurity Patients: Comparison of The Concentration and Purity Index}

Jo Edy Siswanto, ${ }^{*}$ Tiara Berlian, ${ }^{* *}$ Evira Putricahya, ${ }^{* * *}$ Lidya V. Panggalo, ${ }^{* * *}$ Luluk Yuniani****

Background. Retinopathy prematurity (ROP) is a development disorder of blood vessels in the retina that occurs in premature babies. Genetic factors are thought to play role in the incidence of ROP. Concentration and purity measurement in DNA isolation is important for genetic analysis, including cases of ROP.

Objective. To determine concentration and purity index of DNA from blood and buccal cells on premature neonates that fulfils the screening criteria of ROP.

Method. Sixty from a total of 182 subject diagnosed with ROP were selected through systematic random sampling. The concentration is calculated through the absorption of ultraviolet spectrophotometry. Purity index is determined by calculating the ratio between the OD280 and OD260. Statistical analysis was conducted by Kruskal Wallis and Mann Whitney test.

Results. Concentration of DNA test using buffy coat samples is higher than by using whole blood, and buccal swab. Whole blood samples provides highest index of purity.

Conclusion. DNA concentration of buffy coat and whole blood samples is sufficient, and provides good purity index for genetic analysis. Sari Pediatri 2016;18(4):270-7

Keywords: DNA isolation, concentration and purity index, ROP.

Alamat korespondensi: DR. Dr. Jo Edy Siswanto. SpA(K). RSAB Harapan Kita, Jakarta. Email:edyjo15@yahoo.com 
$\mathrm{R}$ etinopati prematuritas (ROP) adalah gangguan perkembangan dari pembuluh darah retina yang mengenai bayi prematur. ${ }^{1-4}$ Beberapa penelitian menyatakan adanya peran komponen genetik pada patogenesis ROP. 5 Skrining pengaruh variasi gen terhadap ROP mungkin akan menyediakan informasi baru mengenai patogenesis ROP yang diharapkan akan menolong identifikasi dan penanganan bayi risiko tinggi tepat pada waktunya. ${ }^{6}$

Gen disusun oleh suatu substansi yang disebut dengan deoxyribonucleic acid atau disingkat DNA. DNA merupakan material genetik yang diturunkan dari generasi ke generasi berikutnya. ${ }^{7}$ Setiap penelitian manipulasi gen memerlukan sumber asam nukleat, dalam bentuk DNA atau RNA. Pengisolasian komponen tersebut dari sel penting dilakukan dengan menggunakan metode yang tersedia. ${ }^{8}$ Ekstraksi DNA merupakan suatu langkah awal pengisolasian molekul DNA. Molekul DNA ini harus diekstraksi dari tempat asalnya. ${ }^{9}$ Pada seluruh jaringan dan cairan tubuh terdapat DNA. Oleh karena itu, DNA genom dapat diisolasi dari semua bahan biologis yang mengandung sel berinti, seperti darah, semen, akar, rambut, tulang dan lain-lain. Namun demikian, bahan yang paling sering digunakan untuk tujuan isolasi DNA adalah darah karena bahan tersebut relatif mudah diperoleh. Sampel darah yang digunakan dapat berupa whole blood (sampel darah total) atau buffy coat. Whole blood (WB) mengandung baik sel-sel berinti (sel darah putih) maupun sel-sel tidak berinti (sel darah merah). Sampel WB dimasukkan ke dalam tabung darah EDTA untuk mencegah pembekuan darah dan dapat menurunkan degradasi DNA. Untuk hasil isolasi DNA yang optimal, penyimpanan sampel darah segar tidak lebih dari 5 hari dalam suhu $4^{\circ} \mathrm{C}$.

Isolasi DNA dari darah dilakukan dengan melisiskan sel darah merah yang tidak mengandung DNA genom agar dapat dipisahkan dari sel darah putih. Sel-sel darah putih yang sudah dipisahkan kemudian dilisiskan dengan bantuan bahan pengawet DNA yaitu, deterjen anionik yang dapat melarutkan komponen selular. Bahan pengawet DNA juga dapat mengurangi aktivitas DNase yang terdapat di dalam sel. Bila perlu dapat ditambahkan RNase untuk menyingkirkan kontaminasi RNA. Selanjutnya dengan presipitasi garam, DNA genom dipisahkan dari protein plasma dan inti. Akhirnya DNA genom diisolasi dengan presipitasi menggunakan alkohol dan pelarutan kembali endapan yang terbentuk dari larutan dapar yang mengandung suatu bahan pengawet DNA. Disamping menggunakan sampel darah segar utuh, isolasi DNA juga dapat dilakukan hanya terhadap sel darah putih. Sampel darah WB yang masih segar langsung dipisahkan menjadi serum, sel darah merah, dan sel darah putih (di lapisan buffy coat) dengan teknik sentrifugasi. Buffy coat adalah konsentrat DNA yang terkandung dalam sel darah putih. Setelah disentrifugasi, sampel darah total akan terbagi menjadi tiga lapisan, yaitu lapisan paling atas merupakan serum, lapisan tengah berwarna putih tipis adalah sel darah putih (buffy coat) dan lapisan bawah adalah sel darah merah. Masing-masing buffy coat yang telah diperoleh kemudian ditambahkan PBS hingga volume mencapai $200 \mu \mathrm{l}$, kemudian sampel disimpan pada suhu $-80^{\circ} \mathrm{C}$. Keuntungan penyimpanan sampel dalam bentuk buffy coat yaitu sampel dapat disimpan lebih lama dan stabil, bahkan masih dapat digunakan untuk analisis genetik sesudah penyimpanan. Namun demikian, untuk mendapatkan buffy coat yang jumlahnya banyak, maka sampel darah segar yang dibutuhkan lebih banyak pula. ${ }^{\mathbf{1 0} 11}$

Cara pengambilan sampel lain yang dapat digunakan adalah buccal swab. Cara menggunakan buccal swab adalah dengan menggosokkan swab pada pipi kanan bagian dalam bayi. Sebaiknya, swab diputar saat digunakan untuk memaksimalkan pemanfaatan kedua sisi kapas. Untuk memaksimalkan hasil sel buccal, swab harus segera dibekukan pada $-80^{\circ} \mathrm{C}$ dan dikirim ke laboratorium sebagai spesimen beku. ${ }^{12}$

Hasil isolasi DNA dikatakan baik apabila didapatkan DNA yang murni dan utuh. Pengukuran konsentrasi DNA maupun penentuan kemurniannya merupakan suatu tahapan yang sangat diperlukan dari serangkaian proses isolasi DNA. Hal ini dilakukan untuk melihat kandungan DNA yang diperoleh secara kuantitatif maupun untuk melihat kontaminan yang mungkin masih ada dari isolat DNA yang diperoleh.

Penelitian ini bertujuan untuk mengetahui konsentrasi dan kemurnian DNA menggunakan sampel buffy coat, whole blood, dan buccal swab pada kelompok bayi prematur yang masuk dalm kriteria penapisan ROP. Sampel diharapkan dapat dipakai untuk analisis penelitian lanjut polimorfisme genetik pada bayi pasien ROP.

\section{Metode}

Sampel yang digunakan dalam penelitian ini berasal dari beberapa rumah sakit di beberapa daerah yang 
berbeda. Sampel diperoleh dari beberapa rumah sakit berikut, 131 sampel diperoleh dari Rumah Sakit Anak dan Bunda Harapan Kita, 25 sampel diperoleh dari Jakarta Eye Center, 14 sampel diperoleh dari Rumah Sakit Ibu dan Anak Budi Kemuliaan, 7 sampel diperoleh dari Rumah Sakit Awal Bros, 4 sampel diperoleh dari Rumah Sakit Royal Taruma, dan 2 sampel diperoleh dari Rumah Sakit PGI Cikini.

Bahan yang digunakan adalah darah perifer 1-2 $\mathrm{ml}$, sel buccal dari mukosa pipi bayi, isopropanol dan High Pure PCR Template Preparation Kit EO/0/15. Alat yang digunakan berupa aplikator swab buccal, tabung darah EDTA, waterbath, spuit disposable $3 \mathrm{ml}$, vorteks, mikropipet 10-100 $\mu \mathrm{l}$, microcentrifugator, mikropipet 100-1000 $\mu$ l, tabung eppendorf $1,5 \mathrm{ml}$, tip biru, nanodrop dan tip kuning.

Prosedur isolasi DNA yang digunakan yaitu sesuai dengan protokol yang tercantum pada high pure PCR template preparation kit $\mathrm{EO} / 0 / 15 .{ }^{13}$ Protokol isolasi DNA yang digunakan tertera pada Tabel 1 .

Konsentrasi DNA dapat dihitung secara akurat melalui penyerapan spektrofotometrik sinar ultraviolet. Jumlah radiasi yang diserap DNA berbanding lurus dengan jumlah DNA dalam sampel. ${ }^{14,15}$ Konsentrasi dinyatakan tinggi bila lebih dari $10 \mathrm{mg} / \mathrm{ml}$. Basa nitrogen akan mengabsorbsi sinar UV, semakin tinggi konsentrasi larutan DNA, akan semakin banyak sinar UV yang terabsorbsi. ${ }^{16}$

Kaidah : Konsentrasi double-stranded DNA murni dengan A260 dari 1.0 adalah $50 \mathrm{mg} / \mathrm{ml}$. Dengan demikian, pernyataan diatas dapat digunakan untuk menentukan rumus konsentrasi DNA dalam satu larutan larutan

$$
\begin{gathered}
\text { Konsentrasi }(\mathrm{mg} / \mathrm{ml}) / \mathrm{A} 260 \text { yang terukur }=50 \\
(\mathrm{mg} / \mathrm{ml}) / 1.0 \text { A260 }
\end{gathered}
$$

Setelah diketahui ada hubungan yang linier antara absorbsi dan konsentrasi DNA, kita dapat menghitung secara aljabar seperti rumus di bawah ini:

$$
\begin{gathered}
\text { Konsentrasi }(\mathrm{mg} / \mathrm{ml})=50 \mathrm{mg} / \mathrm{ml} \text { x A260 yang } \\
\text { terukur x faktor dilusi }
\end{gathered}
$$

Indeks kemurnian DNA berhubungan dengan kualitas DNA. Rasio absorbsi pada $260 \mathrm{~nm}$ dan 280 $n m$ digunakan untuk menilai kemurnian DNA dan RNA. DNA dinyatakan murni jika memiliki nilai rasio

Tabel 1. Protokol isolasi DNA dengan menggunakan high pure por template preparation kit $\mathrm{EO} / 0 / 15$

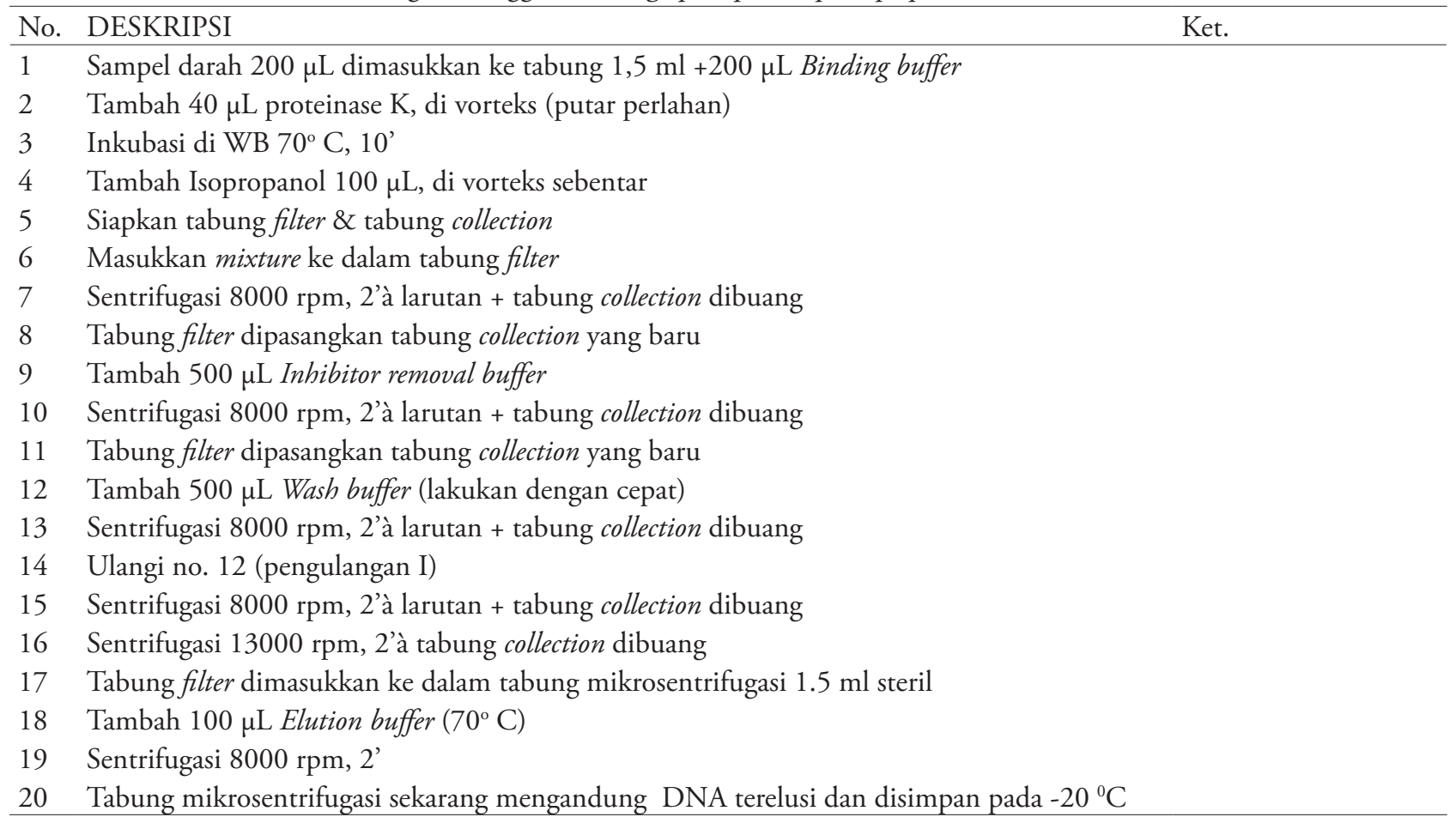


$\mathrm{OD}_{260} / \mathrm{OD}_{280}$ berkisar antara $1,8-2,0 .{ }^{\mathbf{1 0}}$ Pengukuran absorbsi akan menghitung setiap molekul yang terserap pada panjang gelombang tertentu, dan sampel asam nukleat membutuhkan pemurnian sebelum dilakukan pengukuran untuk memastikan hasil yang akurat. Nukleotida, RNA, ssDNA, dan dsDNA semua akan terserap pada $260 \mathrm{~nm}$ dan keseluruhannya akan berkontribusi terhadap total penyerapan. Rasio -1.8 secara umum disebut sebagai ukuran yang "murni" untuk DNA, sedangkan rasio -2.0 diterima sebagai hal yang "murni” untuk RNA. Bila rasio dinyatakan lebih rendah dari nilai tersebut maka hal itu mengindikasikan banyaknya protein, phenol dan berbagai kontaminan yang terserap. ${ }^{23-25}$

Pada penelitian ini konsentrasi dan kemurnian DNA diukur dengan menggunakan nanodrop. Pertama-tama, pilih menu "nucleid acid measurement" dari inisial program window. Kemudian dilanjutkan dengan proses kalibrasi, dengan cara membersihkan tempat pengukuran (berupa titik) menggunakan air milipore dan tissue (kertas pembersih) halus. Setelah bersih $2 \mu \mathrm{L}$ air milipore diletakkan di tempat pengukuran dan ditutup. Klik OK pada box window yang berisi pernyataan apakah anda sedang mengkalibrasi alat. Tunggu hingga alat terkalibrasi. Gagang penutup tempat pengukuran diangkat dan dibersihkan menggunakan air milipore dan tisu halus. Langkah selanjutnya dengan pengukuran blanko, $2 \mu \mathrm{L}$ buffer (yang digunakan untuk melarutkan DNA) diteteskan pada tempat pengukuran, kemudian ditutup dengan gagang tempat pengukuran. Klik "blank". Angkat gagang tempat pengukuran, lalu dibersihkan menggunakan air dan tisu halus. Sekarang klik "start report" untuk mengaktifkan seri pengukuran. Pengukuran dilakukan dengan cara memasukkan nama sampel pada bagian kanan window. Kemudian teteskan $1-2 \mu \mathrm{L}$ sampel pada tempat pengukuran dan tutup. Klik "measure" dan tunggu. Angkat gagang, kemudian bersihkan tempat pengukuran dengan air milipore dan tisu basah. Ulangi prosedur pengukuran jika akan dilakukan pengukuran pada beberapa sampel. Setelah selesai melakukan pengukuran pada semua sampel, maka klik "show report", dan dari window baru pilih "print". Data pengukuran yang telah dilakukan akan dicetak. Selanjutnya klik "exit" untuk menutup semua windows. Tempat pengukuran dibersihkan dengan air milipore dan tisu halus.

Analisis statistik dilakukan untuk melihat kenormalan data dan perbedaaan konsentrasi pada sampel buffy coat, whole blood, dan buccal swab.

- Terdapat 162 data lengkap yang dilaporkan. Sebanyak 134 sampel buffy coat, 17 sampel whole blood, dan 11 sampel buccal swab. Dari data ini, diambil 60 sampel untuk dianalisis. Semua sampel whole blood dan buccal swab diambil (28 sampel), 32 sisanya didapatkan dari hasil random jenis sampel buffy coat. Data sampel buffy coat diurutkan berdasarkan konsentrasi DNA, lalu dipilih 32 sampel secara acak sistematis (systematic random sampling).

- Uji normalitas konsentrasi DNA pada sampel whole blood, buccal swab dan buffy coat.

- Berdasarkan hasil uji normalitas KolmogorovSmirnov dapat diketahui bahwa $p$-value dari variabel kemurnian dan konsentrasi DNA sebesar 0,010 dan 0,000 . Oleh karena probabilitas $<0,05$, maka dapat diketahui bahwa data tersebut tidak berdistribusi normal. Karena data tidak berdistribusi normal, uji statitik dilakukan dengan uji statistik non-parametrik.

- Uji statistik non-parametrik Kruskal Wallis dilakukan untuk melihat perbedaan rata-rata kemurnian dan konsentrasi DNA antar jenis sampel. Jika ditemukan perbedaan, dilakukan uji post-hoc dengan Mann Whitney.

\section{Hasil}

Hasil penelitian menunjukkan bahwa terdapat perbedaan konsentrasi DNA yang berasal dari sampel buffy coat, whole blood, dan buccal swab. Hasil pengukuran konsentrasi dan kemurnian DNA dapat tertera pada Tabel 2 dan 3. Distribusi kelompok indeks kemurnian berdasarkan jenis sampel DNA tertera pada Tabel 4.

Berdasarkan data yang diperoleh, dapat dilihat bahwa rata-rata konsentrasi DNA dari jenis sampel buffy coat lebih tinggi dibandingkan sampel whole blood yaitu sebe sar 30,32 ng/ $\mu$ l. Hasil analisis statistik menunjukkan bahwa $p$-value sebesar 0,000 (Tabel 3). Oleh karena probabilitas $<0,05$, maka $\mathrm{H}_{0}$ ditolak atau terdapat perbedaan konsentrasi DNA yang bermakna antar sampel. Pada test post-hoc dengan Mann Whitney, perbedaan konsentrasi DNA terlihat antara sampel buffy coat dengan buccal swab dan whole blood dengan buccal swab (hasil p-value keduanya $<0,05)$. Sedangkan pada sampel buffy coat dan whole 
Jo Edy Siswanto dkk: Isolasi DNA pada sampel darah tepi dan swab buccal pada bayi ROP

Tabel 2. Distribusi indeks kemurnian dan konsentrasi DNA berdasarkan sampel

\begin{tabular}{|c|c|c|c|c|c|}
\hline \multirow{2}{*}{ Jenis sampel } & \multirow{2}{*}{ Rerata } & \multirow{2}{*}{ Median } & \multirow{2}{*}{ SD } & \multicolumn{2}{|c|}{$95 \%$ CI rerata } \\
\hline & & & & LL & UL \\
\hline \multicolumn{6}{|c|}{ Kemurnian DNA } \\
\hline Buffy coat & 1,8634 & 1,8450 & 0,5978 & 1,6479 & 2,0790 \\
\hline Whole blood & 1,7924 & 1,8800 & 0,5465 & 1,5114 & 2,0733 \\
\hline Buccal swab & 0,9309 & 0,8300 & 0,4773 & 0,6103 & 1,2515 \\
\hline \multicolumn{6}{|c|}{ Konsentrasi DNA } \\
\hline Buffy coat & 30,3156 & 19,8500 & 33,0431 & 18,4023 & 42,2289 \\
\hline Whole blood & 30,2765 & 30,9000 & 21,8808 & 19,0264 & 41,5266 \\
\hline Buccal swab & 2,9136 & 1,7000 & 3,1526 & 0,7957 & 5,0316 \\
\hline
\end{tabular}

Tabel 3. Hasil uji beda mean kemurnian dan konsentrasi DNA berdasarkan sampel

\begin{tabular}{lc}
\hline Uji statistik & $\mathrm{p}$ \\
\hline Kemurnian DNA & 0,000 \\
Krukal-Wallis & 0,908 \\
Mann Whitney (buffy coat-whole blood) & 0,000 \\
Mann Whitney (buffy coat- buccal swab) & 0,000 \\
Mann Whitney (whole blood-buccal swab) & \\
Konsentrasi DNA & 0,000 \\
Krukal-Wallis & 0,469 \\
Mann Whitney (buffy coat- whole blood) & 0,000 \\
Mann Whitney (buffy coat- buccal swab) & 0,000 \\
Mann Whitney (whole blood-buccal swab) & \\
\hline
\end{tabular}

Tabel 4. Distribusi kelompok indeks kemurnian berdasarkan jenis sampel DNA

\begin{tabular}{lcccccc}
\hline \multirow{2}{*}{ Jenis sampel DNA } & \multicolumn{2}{c}{$\begin{array}{c}\text { Indeks kemurnian DNA } \\
\text { baik }\end{array}$} & \multicolumn{2}{c}{$\begin{array}{c}\text { Indeks kemurnian } \\
\text { DNA buruk }\end{array}$} & \multicolumn{2}{c}{ Total } \\
\cline { 2 - 7 } & $\mathrm{N}$ & $\%$ & $\mathrm{n}$ & $\%$ & $\mathrm{n}$ & $\%$ \\
\hline Buffy coat & 10 & 31,2 & 22 & 68,8 & 32 & 100,0 \\
Whole blood & 8 & 47,1 & 9 & 52,9 & 17 & 100,0 \\
Buccal swab & 0 & 0,0 & 11 & 100,0 & 11 & 100,0 \\
N sampel & 18 & 30,0 & 42 & 70,0 & 60 & 100,0 \\
\hline
\end{tabular}

blood, walaupun rata-rata konsentrasi DNA buffy coat sedikit lebih tinggi, tidak ditemukan adanya perbedaan konsentrasi DNA yang signifikan antara kedua sampel tersebut ( $p$-value 0,469). Dengan demikian, dapat dikatakan bahwa sampel buffy coat dan whole blood dapat digunakan dalam proses isolasi DNA karena konsentrasinya lebih tinggi daripada sampel buccal swab.

Indeks kemurnian diukur dengan nanodrop. Hasil penelitian menunjukkan bahwa nilai median kemurnian pada sampel whole blood yaitu sebesar
1,88 , sedangkan median kemurnian pada sampel buffy coat dan buccal swab masing-masing 1,85 dan 0,83 . Uji statistik dilakukan untuk melihat perbedaan indeks kemurnian DNA antar sampel. Perbedaan yang signifikan ditemukan antara variabel buffy coat dengan buccalswab dan whole blood dengan buccal swab $(\mathrm{p}<0,05)$. Tidak ditemukan perbedaan yang signifikan $(\mathrm{p}=0,98)$ antara indeks kemurnian DNA pada sampel buffy coat dengan whole blood (Tabel 3). Jika kita lihat, dari keseluruhan sampel hanya sebagian kecil $(30,00 \%)$ yang memiliki kemurnian DNA yang baik. Proporsi 
kemurnian DNA yang dalam kategori baik, presentase yang terbesar terdapat pada sampel whole blood, yaitu 47,1\%. Sebaliknya pada sampel buffy coat dan buccal swab, ditemukan proporsi kemurnian DNA dalam kategori baik adalah masing-masing $31,2 \%$ dan $0,0 \%$ (Tabel 4).

\section{Pembahasan}

Konsentrasi DNA tertinggi didapatkan pada sampel buffy coat. Hal ini dapat disebabkan karena pada sampel buffy coat hanya terkonsentrasi sel-sel darah putih yang mengandung inti sel, terdapat DNA genom di dalamnya, sedangkan pada sampel whole blood masih terdapat komponen sel darah merah yang tidak mengandung DNA genom. Dellman dan Brown, ${ }^{17}$ menyatakan bahwa eritrosit mamalia dewasa tidak berinti, sedangkan leukosit memiliki nukleus (inti sel). DNA bersama-sama protein dan molekul RNA terdapat dalam inti sel. Jumlah leukosit yang dipanen berbanding lurus dengan konsentrasi DNA yang dihasilkan karena DNA ada di dalam inti sel yang hanya dimiliki oleh leukosit. Oleh sebab itu, meskipun dalam jumlah sampel yang sama $(200 \mu \mathrm{l})$, konsentrasi DNA yang diperoleh pada sampel buffy coat lebih tinggi dibandingkan sampel whole blood. Pada penelitian ini terlihat nilai konsentrasi tertinggi didapatkan pada sampel buffy coat dibandingkan dengan sampel whole blood ataupun buccal swab yakni $146,8 \mathrm{ng} / \mu \mathrm{l}, 82,5 \mathrm{ng} / \mu \mathrm{l}$, dan $10,4 \mathrm{ng} / \mu \mathrm{l}$. Namun demikian, untuk memperoleh jumlah buffy coat yang memadai, dibutuhkan sampel darah yang lebih banyak, sedangkan pada pasien bayi prematur pengambilan darah dengan jumlah yang banyak cukup sulit untuk dilakukan. Pada sampel whole blood jumlah darah yang dibutuhkan untuk isolasi DNA tidak banyak karena yang digunakan dalam proses isolasi DNA hanya $200 \mu \mathrm{l}$ sehingga dengan jumlah sampel whole blood $1000 \mu \mathrm{L}$ $(1 \mathrm{~mL})$ saja sudah mencukupi untuk diproses. Pada penelitian ini jumlah darah yang diambil bervariasi antara 0,5-2,0 mL. Sampel darah yang digunakan berasal dari bayi prematur dengan berat badan $<2500$ gr, bahkan pada sebagian kasus dengan berat badan lahir $<1000$ gram. Dengan kondisi demikian, jenis sampel whole blood lebih memungkinkan dan lebih nyaman untuk digunakan pada pengambilan sampel.

Dari uraian tersebut, dipastikan bahwa ekstraksi DNA dapat dilakukan dengan menggunakan sampel darah dalam jumlah volume yang sedikit (minimal $0,5 \mathrm{ml}$ ), terutama jika ditemukan kesulitan dalam memperoleh sampel darah dalam volume besar. Meskipun demikian, sampel buffy coat memiliki beberapa keuntungan lain yaitu sampel dapat disimpan lebih lama dan stabil serta dapat digunakan untuk analisis mRNA dan ekspresi gen, sedangkan pada sampel darah segar penyimpanan tidak boleh lebih dari 5 hari agar diperoleh hasil isolasi DNA yang maksimum.

Pada cara pengambilan buccal swab, diperoleh konsentrasi DNA yang terendah. Walaupun demikian, cara pengambilan sampel ini merupakan cara pengambilan sampel DNA yang paling reliabel dan dapat diterima pada kelompok anak karena merupakan cara yang paling tidak invasif untuk pengumpulan sampel DNA. ${ }^{18}$ Penelitian Hansen ${ }^{19}$ di Denmark mencoba menganalisis perbandingan response rate dan kualitas DNA genomik dari sampel darah, air liur, dan sel buccal yang dikumpulkan oleh para perawat. Hasil penelitian menunjukkan bahwa response rate terbesar diperoleh pada sampel swab buccal (80\%), disusul oleh sampel buccal FTA (Flinders Technology Associates) card, air liur, dan darah (response rate masing-masing adalah 76\%, 72\%, dan 31\%). Walaupun demikian, dari sisi kualitas gen DNA yang dihasilkan hanya sampel yang berasal dari air liur yang memiliki kualitas yang sebanding dengan sampel darah.

Konsentrasi DNA yang didapat pada jenis sampel buccal swab sangat sedikit. Oleh karena itu, disarankan untuk mengambil sampel sel buccal pada mukosa pipi bagian dalam rongga mulut pasien dengan jumlah sikat swab/aplikator yang lebih banyak atau diambil beberapa kali. Sangat baik bila disiapkan setidaknya 4 swab sebagai sampel. Ekstraksi DNA dari sel buccal memang lebih sedikit daripada DNA dari darah. Banyak mikroorganisme dalam mulut sehingga dapat mengurangi kualitas DNA yang diperoleh. Tempat atau posisi pengambilan sel buccal juga memengaruhi banyaknya DNA yang diperoleh. Nedel $\mathrm{dkk}^{20}$ melakukan perbandingan banyaknya DNA yang diperoleh dari bagian upper gutter dengan lower gutter. Hasil yang diperoleh menunjukkan kemurnian DNA yang diperoleh dari upper gutter lebih baik dibandingkan lower gutter. yaitu 1,79 untuk upper gutter dan 1,66 untuk lower gutter. Hal lain yang menjadi perhatian adalah konsentrasi DNA yang diperoleh dari buccal swab yang tidak langsung diisolasi akan lebih sedikit dibandingkan buccal swab yang 
langsung diisolasi. DNA yang diperoleh dari buccal swab yang langsung diekstraksi memiliki konsentrasi sebesar $83 \mathrm{ng} / \mu \mathrm{l}$, sedangkan DNA yang diperoleh dari buccal swab yang disimpan selama 3 hari pada $-20^{\circ} \mathrm{C}$ pada individu yang sama memiliki konsentrasi $55 \mathrm{ng} /$ $\mu$ l. $^{21}$ Sampel swab buccal dapat dikeringkan untuk penyimpanan jangka panjang. Swab dikeringkan sekitar 2 jam pada suhu kamar dan sesudah kering swab dapat disimpan dalam wadah yang cocok. Swab dapat ditempatkan ke dalam tabung microcentrifuge $2 \mathrm{ml}$ yang tertutup. Swab yang sudah kering dapat disimpan lebih dari 1 tahun tanpa mempengaruhi DNA. Untuk memproses swab tadi, dapat dikirim dengan tabung yang tertutup tersebut ke laboratorium pemeriksaan yang dituju. ${ }^{22}$

Kemurnian DNA yang didapatkan relatif rendah. Hal ini dapat disebabkan protein yang tercampur pada DNA yang dihasilkan. Sambrook $\mathrm{dkk}^{10}$ menjelaskan bahwa rasio OD akan lebih besar atau lebih kecil dari nilai 1,8-2,0 jika ditemukan kontaminasi dari protein atau fenol. Yunaini ${ }^{26}$ juga menyatakan bahwa jika nilai indeks kemurnian DNA lebih kecil dari 1,8 maka DNA tersebut terkontaminasi oleh protein. Hasil pemeriksaan kemurnian DNA pada sampel whole blood dan buffy coat menunjukkan bahwa DNA yang diisolasi murni karena DNA memiliki indeks kemurnian >1,8 .

\section{Kesimpulan}

Konsentrasi DNA pada sampel buffy coat dan whole blood yang dihasilkan pada penelitian ini cukup besar dengan indeks kemurnian yang baik. Sedangkan pada sampel buccal swab, ditemukan konsentrasi dan indeks kemurnian yang rendah. Pengukuran DNA pada penelitian ini dilakukan dengan menggunakan spektrofotometer yang didasarkan pada prinsip iradiasi ultra violet yang diserap oleh nukleotida dan protein dalam larutan. Dengan demikian, kemurnian yang dihitung termasuk kontaminannya juga (protein). Indeks kemurnian DNA yang rendah tidak menutup kemungkinan DNA tersebut untuk digunakan pada penelitian yang berbasis teknologi DNA. Penelitian teknologi DNA yang memerlukan DNA dalam jumlah banyak dan tidak menuntut indeks kemurnian yang tinggi, diantaranya pemetaan genetik, teknologi marker, dan sequencing DNA. Dapat diambil kesimpulan bahwa isolasi dan ekstraksi DNA sampel whole blood dan buffy coat yang didapatkan oleh peneliti dari bayi prematur penderita ROP dapat dipakai dalam proses penelitian untuk polimorfisme genetik yang akan dilakukan selanjutnya. Konsentrasi DNA rata-rata yang berasal dari sampel buffy coat lebih tinggi dibandingkan konsentrasi DNA rata-rata dari whole blood dan buccal swab. Konsentrasi tertinggi didapatkan pada sampel buffy coat adalah 146,8 ng/ $\mu$ l. Perbedaan bermakna ditemukan antara konsentrasi DNA yang berasal dari sampel whole blood dengan buccal swab dan buffy coat dengan buccal swab. Hasil pemeriksaan kemurnian DNA menunjukkan bahwa sampel whole blood memiliki kemurnian DNA yang lebih baik jika dibandingkan sampel buffy coat dan buccal swab. Sampel buccal swab walaupun memiliki konsentrasi dan indeks kemurnian yang rendah namun penggunaan sampel ini tetap dapat dipertimbangkan karena pengambilan sampel ini cenderung lebih mudah diterima oleh pasien bayi/anak.

\section{Daftar pustaka}

1. Azad. Retinopathy of prematurity. New Delhi Dr. Rajendra Prasad Centre for Ophtalmic Sciences. All India Institute of Medical Science 2006:8-106.

2. Terry TL. Extreme prematurity and fiberplastic overgrowth of persistent vasculer sheath behind each crystalline lens. I.A Preliminary report. J Ophtalmol 1942;25:203-4.

3. Smith LE. Review article. Pathogenesis of retinopathy of prematurity. Departement of Ophtalmology, Children's Hospital Harvard Medical School-Boston. Semin Neonatol 2003;8:469-73.

4. The International Committee for the Classification of the Late Stages of Retinopathy of Prematurity. An international classification of retinopathy of prematurity. II. The classification of retinal detachment. Arch Ophthalmol 1987;105:906-12.

5. Wheatley CM, Dickinson J.L, Mackey DA. Retinopathy of prematurity: recent advanced in our understanding. Br J Ophthalmol 2002;86:696-700.

6. Piccioni A, Lanners J, Goergen E. Early rehabilitation in retinopathy of prematurity children ( $0-4$ years). Progress in retinopathy of prematurity. Proceedings of the international symposium on retinopathy of prematurity, 1997, Taormina, Italy. Amsterdam/New York: Kugler Publications, 1997.

7. Russel PJ. Genetics. Edisi ke-2. Ilinois: Scott, Foresman and Company; 1990.

8. Nicholl DST. An introduction to genetic engineering. Crambridge: Cambridge University Press;2002.

9. Murray RK. Biokimia Harper. Edisi ke-29. Jakarta: ECG 
Penerbit Buku Kedokteran;2014.

10. Sambrook J, Fritsch EF, Maniatis T. Molecular cloning: a laboratory manual. Edisi ke-4. New York: Cold Spring Harbor Laboratory Press;2012.

11. Mychaleckyj JC. Buffy coat specimens remain viable as a DNA source for highly multiplexed genome-wide genetic tests after long term storage. Journal of Translational Medicine 2011; 9:91.

12. Rogers NL, Cole SA, Lan HC, Crossa A, Demerath EW. New saliva DNA collection method compared to buccal cell collection techniques for epidemiological studies. Am J Hum Biol 2007;19:319-326.

13. High Pure PCR Template Preparation Kit - Roche. Diunduh pada 12 Desember 2016. Didapat dari: www. roche-applied-science.com, high pure pcr template preparation kit version 20. Oktober 2012.

14. Brown TA. Gene Cloning and DNA Analysis: An Introduction. Edisi ke-6. New York; Chapman and Hall: 2010.

15. Ayu Wulandhari. Optimalisasi hasil ekstraksi DNA dari darah segar sapi menggunakan high salt method dengan perbandingan darah dan lisis buffer pada kecepatan sentrifugasi berbeda, skripsi. Departemen Ilmu Produksi dan Teknologi Peternakan, Fakultas Peternakan, Institut Pertanian Bogor, 2009.

16. Determination of DNA concentration by Spectrophotometric Estimatio. Diunduh pada 12 Desember 2016. Didapat dari: http://homepages.bw.edu/ - mbumbuli/molbio/labs/dnal

17. Dellman HD, Brown EM. Buku teks histologi veteriner II. Edisi ke-3. Terjemahan : R. Hartono. Jakarta: Penerbit Universitas Indonesia;1992.

18. Beckett SM, Laughton SJ, Dalla Pozza L, McCowage GB, Marshall G, Cohn RJ. Ashton LJ. Buccal swabs and treated cards: methodological considerations for molecular epidemiologic studies examining pediatric populations. Am J Epidemiol 2008;16:1260-7.

19. Hansen TVO, Simonsen MK, Nielsen FC, Hundrup YA. Collection of blood, saliva, and buccal cell samples in a pilot study on the Danish nurse cohort: comparison of the response rate and quality of genomic DNA. Cancer Epidemiol Biomarkers \& Prevention 2007;16:2072-6.

20. Nedel F, Conde MCM, de Oliveira IO,Tarquinio SBC, Demarco FF. Comparison Between DNA Obtained From Buccal Cells of the Upper and Lower Gutter Area. Braz Dent J 2009;20: 275-8.

21. Ghatak S, Muthukumaran RB, Nachimuthu SK. A Simple Method of Genomic DNA Extraction from Human Samples for PCR-RFLP Analysis. J Biomolecular Techniques 2013;24:224-31.

22. Genomed catalogue 2008-2009. Jetquick protocol for the purification of DNA from buccal swabs and whole blood. Diunduh pada 12 Desember 2016. Didapat dari: http://www. brunschwigch.com/pdfldownloads/GE_JetQuick_DNA_ buccal_Protocol.pdf.

23. NanoDrop. Technical Support Bulletin T009. 260/280 and 260/230 Ratios NanoDrop ${ }^{\circ}$ ND-1000 and ND-8000 8-Sample Spectrophotometers. Diunduh pada 12 Desember 2016. Didapat dari: www.bio.davidson.edu/GCAt/protocols/ NanoDrop_tip.pdf.

24. Held PG. Nucleic acid purity assessment using A260/A280 ratios. 2006. Diunduh pada 12 Desember 2016. Didapat dari: http://www.biotek.com/resources/docs/PowerWave200_Nucleic_ Acid_Purity_Assessment.pdf.

25. NanoDrop Technologies. 260/280 and 260/230 Ratios NanoDrop ND-1000 and ND-8000 8-Sample Spectrophotometers. Diunduh pada 12 Desember 2016. Didapat dari: http://www.bio.davidson.edu/projects/gcat/protocols/ NanoDrop_tip.pdf. 2007.

26. Yunaini. Isolasi DNA, primer design (desain primer), polymerase chain reaction (PCR), restrictive leng polymorphism (RLFP), DNA sequencing (sekuencing DNA) dan analisa sekuensing DNA, laporan praktikum genetika molekuler. Jakarta: Program Pasca Sarjana, Program Studi Ilmu Biomedik. Universitas Indonesia, 2010. 